\title{
Looking at Athletics in the Fourth Century: The Unification of the Spectacle Landscape in East and West
}

\author{
Sofie Remijsen
}

\section{Games and the Roman Empire}

The western and eastern Mediterranean both had their own traditions of what scholarship today usually calls 'games': events held in large structures, often in stone, with hundreds or thousands of seats arranged around a central stage, on which a few protagonists were engaged in demanding feats of sports or arts that excited the assembled crowd. Although the word 'games' is a translation of ludi, it is in reality a modern category that covers a far larger spectrum of events than this Latin term. In the Greek cultural tradition, games were usually organized in the competitive format of the agon: free citizens voluntarily competed against their peers in athletics or in performing arts. In the Roman Republic, ludi were not necessarily competitive; chariot races were of course a contest, but theatrical shows were not. At the munera in the amphitheater, gladiators fought each other or venatores fought wild animals. The protagonists of the ludi and munera were not highly respected citizens who had volunteered to participate, but a mix of slaves and free men, whose citizen rights had been confined.

Research of the previous decades has convincingly shown how, despite the obvious differences, both traditions of games could play a comparable sociopolitical role in the political culture of the Roman Empire, because they shared a central feature: they offered the ruling classes the opportunity to make a positive connection with the crowd. Euergetism was a central element of the political culture in East and West alike. The organization of any type of games required a considerable organizational effort by wealthy sponsors, which was acknowledged by the community, which in return honored them with their cheers and other signs of appreciation. ${ }^{1}$ The benefactor in this way converted

1 For a general discussion of euergetism see Arjan Zuiderhoek, The Politics of Munificence in the Roman Empire. Citizens, Elites, and Benefactors in Asia Minor (Cambridge, Eng., 2009), esp. pp. 6-12.

(C) SOFIE REMIJSEN, 2015 | DOI 10.1163/9789004291935_009

This is an open access chapter distributed under the terms of the Creative Commons Attribution-

Noncommercial 3.0 Unported (CC-BY-NC 3.0) License. 
his economic capital into social capital, and saw his elevated position in society confirmed. Games not only confirmed the power of the local ruling classes, but also of the emperor. It was indeed important for a Roman emperor to be present at the games, for these were occasions where he interacted closely with the people. They could approach him with petitions and he was expected to react to these in an interested, civil manner. This climate even allowed for criticism, but riots were a rare event. The normal state was social harmony, for the exuberant atmosphere at the games normally created positive emotions towards the ruler, who was loudly acclaimed. ${ }^{2}$

Emperors were hence present at all kinds of games in the capital: he (or a carefully chosen representative) attended ludi or munera in Rome, which he had sponsored from his own fortune or which had been sponsored by Roman magistrates as part of their office. When he travelled through the Empire, he attended locally organized games. In the Greek-speaking part of the Empire these were typically agones. Already during the first decades of the Empire, Augustus showed that such athletic games were perfectly acceptable alternatives to the more traditional Western games. He famously attended the Sebasta in Naples shortly before he died. ${ }^{3}$ In AD 86, Domitian even introduced a permanent agon in Rome, the Capitolian games. ${ }^{4}$

Even without imperial presence, games could be used to send out ideological messages. The exotic animals and ethnic stereotypes in the munera sent a strong message of power because they visualized the extent of the Empire. Ludi were often organized on imperial feast days (to celebrate a birthday, an anniversary of the reign, or a military triumph). In the eastern Mediterranean, emperors were more likely to celebrate an important event with an agon. Augustus, for example, celebrated his triumph at Actium with the construction of

2 For the emperor at the games see Alan Cameron, Circus Factions. Blues and Greens at Rome and Byzantium (Oxford, 1976), pp. 157-192. A brief summary of this relation in Francesca Garello, "Circenses. Sports as a Vehicle of Popular Consesus and Control of the Masses in Imperial Rome," in La comune eredità dello sport in Europa. Atti del $1^{\circ}$ Seminario Europeo di Storia dello Sport, eds. Arnd Krüger and Angela Teja (Rome, 1997), pp. 100-106.

3 Suetonius, Augustus 98.5; Velleius Paterculus 2.123.1. The Sebasta in Naples were not instituted by Augustus. According to Cassius Dio 55.10.9, the people of Naples wanted to honor their emperor to thank him for his financial help after an earthquake.

4 Nero had already attempted the same, but the Neroneia ended with his damnatio memoriae. The evidence for the Neroneia and the Kapitolia is collected in Maria Letizia Caldelli, L'Agon Capitolinus. Storia e protagonisti dall' istituzione domizianea al IV secolo (Rome, 1993), pp. 37-43, 53-90. See also Louis Robert, "Deux concours grecs à Rome," Comptes Rendus de l'Académie des Inscriptions et Belles-lettres (1970), pp. 6-27 for the agones introduced in Rome in the third century. 
the victory town Nikopolis and the institution of a quadrennial agon, the Aktia. ${ }^{5}$ Although this contest is exceptional - normally emperors had only a reactive role in the institution of games, which was driven by cities - the link with the imperial power is not. The inclusion in the Roman Empire in fact stimulated the growth of the agonistic circuit ${ }^{6}$ - there were never more agones than in the second and third centuries AD. Cities instrumentalized their local feasts to reach out to the emperor in many ways. In practically all cases, they asked the court for permission. This not only had practical advantages - it gave the financial arrangements greater legal protection and removed all discussion whether the games had 'sacred' status - but also improved the relation between emperor and city. In the third century AD, when along the endangered borders of the Empire the emperors needed all the support they could get they were particularly generous with their permissions of high status games. ${ }^{7}$ Many of the new contests proposed by the cities were, moreover, named after the emperor and held in his honor rather than or besides that of a traditional god. Even agones named after local benefactors or traditional deities, honored the reigning emperor with pictures in the procession. In this way, the cities could combine a strong sense of local civic pride with the expression of loyalty to the Roman emperor. ${ }^{8}$ On the level of the provincial koina, where local traditions were less embedded, the imperial cult was often combined with Roman-style games. Gladiatorial games, often in combination with venationes, are therefore relatively well-attested in the eastern part of the Empire in the first three centuries AD. Like the agones, they were promoted by the local elites and not intro-

5 Suetonius, Augustus 18.2; Strabo 7.7.6. Another example is Septimius Severus' involvement in the Olympia Severeia at Kodrigai in Cilicia, which celebrated his victory over Pescennius Niger. Cf. Ruprecht Ziegler, Städtisches Prestige und kaiserliche Politik: Studien zum Festwesen in Ostkilikien im 2. und 3. Jahrhundert n. Chr. (Düsseldorf, 1985), pp. 22-25, 33-34 and 75-85.

6 Onno van Nijf, "Local heroes: athletics, festivals and elite self-fashioning in the Roman East," in Being Greek under Rome. Cultural Identity, the Second Sophistic and the Development of Empire, ed. Simon Goldhill (Cambridge, Eng., 2001), pp. 306-334, esp. pp. 314-320.

7 This has been shown especially by Ruprecht Ziegler, Städtisches Prestige, pp. 67-119 and Christian Wallner, Soldatenkaiser und Sport, Grazer Altertumskundliche Studien 4 (Frankfurt am Main, 1997), esp. p. 231. More general ideas about the emperors and the agones were published by Tony Spawforth, "Kapetoleia Olympia: Roman Emperors and Greek Agones," in Pindar's Poetry, Patrons, and Festivals from Archaic Greece to the Roman Empire, eds. Simon Hornblower and Catherine Morgan (Oxford, 2007), pp. 377-390.

8 Mary T. Boatwright, Hadrian and the Cities of the Roman Empire (Princeton, 200o), pp. 95-98. More general discussion in Zahra Newby, Greek Athletics in the Roman World. Victory and Virtue (Oxford, 2005), pp. 1-14. 
duced under government pressure ${ }^{9}$. A final, and more specific, way in which games contributed to an identification of the Greek-speaking population with the Roman Empire, is by the award of Roman citizenship. Competing on the agonistic circuit, or more precisely winning a Greek-style contest in Rome, was indeed one of the best attested ways of receiving Roman citizenship before the Constitutio Antoniniana. All the victors of the Kapitolia received the tria nomi$n a$ of the reigning emperor. ${ }^{10}$ Participation in certain agones could therefore, just like the organization of agones, be a way of becoming Roman while staying Greek.

This brief summary of the political role of games - a topic that has been intensively studied over the last decades - shows that both Greek-style and Roman-style games contributed to the political unity of the early Empire. It hides from our view, however, that games they did not contribute to cultural unity in the Roman Empire of the first three centuries AD. Despite a modest level of interaction, which made athletics fashionable in the Roman West and led to the introduction of agones in several western cities with a large Philhellenic population (Rome, Naples, Puteoli, Vienne (briefly), Marseilles and Nîmes (for artists), Cherchell and Carthage ${ }^{11}$ and to the organization of gladiatorial games during the feasts of the eastern provincial koina, East and West remained largely separate cultural realms with respect to games. This paper aims to bring often understated cultural differences to the center of attention: until the fourth century, the local set of games still dominated and determined the taste and perceptions of people, which affected, among other things, the status of the participants, the identification and interaction of the spectators with the participants, and the (self-)representation of the participants. I will

9 Michael J. Carter, "Romanization through Spectacle in the Greek East," in A Companion to Sport and Spectacle in Greek and Roman Antiquity, eds. Paul Christesen and Donald G. Kyle (Malden and Oxford), pp. 619-621. Christian Mann, "Um keinen Kranz, um das Leben kämpfen wir!" Gladiatoren im Osten des römischen Reiches und die Frage der Romanisierung (Berlin, 2011), pp. 54-57, 64-67. For a graph of the proportion of agonistic festivals, gladiatorial games and venationes in Asia Minor see Arjan Zuiderhoek, The Politics of Munificence, p. 88.

See Peter Herz, "Seltsame Kaisergentilizien. Beobachtungen zur kaiserzeitlichen Nomenklatur," in Fremde Zeiten. Festschrift für Jürgen Borchhardt, eds. Fritz Blakolmer e.a. (Wien, 1996), pp. 253-259.

For the fashionable character of athletics in the West see Newby, Greek Athletics in the Roman World, esp. pp. 134-140. For the main sources and discussions on the western agones see Sofie Remijsen, The End of Greek Athletics (Cambridge, Eng., 2015), pp. 129163. 
argue that a real unification of the entertainment sector, including the spread of similar perceptions of games in East and West, took place only in the fourth century $\mathrm{AD}$, when the political unity started to disappear.

\section{A Meeting with a Third-Century Athlete}

In order to efficiently explore differences in perception, this section takes as protagonist a fictional average citizen with, however, more than average means, from a city in the Greek-speaking part of the Roman Empire of the early third century AD - let us call him Apollonios. We imagine a particular occasion, in which Apollonios went to see an agon in his own city. While sitting in the stadium he recognized several of the competitors. Some he knew only by name. If the agon he attended was a top contest, some of the competitors would indeed have been world-famous. Not all of them would have been, however, certainly not if the agon did not enjoy sacred status, or in the competitions for youngsters. The contest Apollonios watched on this particular occasion was an agon with a mostly local catchment area. Two of the boys competing were Apollonios' nephews; a third was the son of a good friend. One of the victors in the men's competition was the man who used to defeat Apollonios when they were training together in the ephebate - the voluntary citizen training with a strong athletic focus that was well-established in the Hellenistic and Roman period. Because Apollonios, who like most of his peers had only an average talent for athletics, had spent a considerable part of his youth training in the gymnasium, he could recognize the technical quality of even the more subtle moves of the wrestlers or pankratiasts. He could calculate who was winning the pentathlon before the herald had proclaimed the victor. He could even imagine that, if he had just had a little more talent and better trainer in his early youth, it would have been him in the ring. By now, however, Apollonios had grown too old for that, so instead he paid special attention to the young man who came first in the diaulos - the second cousin of a good friend who currently officiated as gymnasiarch. The young man would make a good match for his daughter. His accomplishments showed that he had admirable self-control and discipline, and a healthy ambition to excel. Apollonios would happily link his own family to the glory of the young man's victories. These victories were, moreover, bound to ensure the athlete a seat in the city council and interesting tax privileges. Apollonios had high hopes for him. 
Though Apollonios and his candidate son-in-law ${ }^{12}$ are entirely fictitious, the situation sketched is not. In the eastern part of the Roman Empire, athletics formed a considerable part of the education of that section of the urban population that could afford to invest in the cultural capital of their children. Athletic teachers for young boys were available in most gymnasia and in most cities teenage citizens-to-be (those who could be spared at home) would likewise be registered in the ephebate. The lack of a direct purpose behind this training, beyond health, was occasionally observed, but did not make it invaluable, for the athletic training ingrained highly valued attitudes such as a love of hard work (philoponia) or a keenness to be honored as the best (philotimia) in the next generation. ${ }^{13}$ That one required free time and money to engage in it moreover confirmed the elite status of those who did indeed engage in it. Men of the higher layers of society thus usually had personal experiences in the sports in which the athletes competed at the agones. ${ }^{14}$ Most competitors on the agonistic circuit came from among their midst and enjoyed a high status in society. ${ }^{15}$ Although criticism of professional athletes was uttered in intellectual circles, ${ }^{16}$ it was equally normal to associate athletes with virtues. The most famous example is Dio's praise of Melankomas:

The son-in-law is introduced because in modern sociological studies the willingness to include a performer in one's family is used as a reliable criterion for the status and perception of performers, cf. Karin van Nieuwkerk, "A Trade like Any Other": Female Singers and Dancers in Egypt (Austin, Tex., 1995), pp. 187-192.

At ephebic competitions in the Hellenistic period there were special prizes for the young men who were most accomplished in showing perfect form ( $\varepsilon \dot{\varepsilon} \varepsilon \xi i \alpha)$, an exertion-loving attitude $\left(\varphi i \lambda \circ \pi \circ v^{\prime} \alpha\right)$, and the best behavior ( $\varepsilon \dot{\tau} \tau \alpha \xi i \alpha$, later $\left.\varepsilon \dot{x} x \circ \sigma \mu i \alpha\right)$. Cf. Nigel B. Crowther, "Euexia, eutaxia, philoponia: Three contests of the Greek gymnasium," Zeitschrift für Papyrologie und Epigraphik 85 (1991), 301-304. The competitive format, with which the ephebes' moral as well as athletic qualities were measured, stimulated individual ambition.

On the role of athletic education for the elite in the Roman East see in particular Onno van Nijf, "Athletics and Paideia: Festivals and Physical Education in the World of the Second Sophistic," in Paideia: The World Of The Second Sophistic, ed. Barbara E. Borg (Berlin - New York 2004), pp. 203-227.

15 See especially Henri W. Pleket, "Zur Soziologie des antiken Sports," Mededelingen van het Nederlands Instituut te Rome 36 (1974), 57-87, and more recently, Onno van Nijf, "Local heroes," pp. 321-329.

16 Objections to gluttony: e.g. Euripides, Autolycus Fr. 282, 4-6; Athenaeus 10.412 d-f; Galen, Protrepticus 11; Clement, Paedagogus 3.10; Tatian, Oratio ad Graecos 23. Objections to the uselessness of athletics: e.g. Tyrtaeus, Fr. 12, 1-16; Lucian, Anacharsis 31; Xenophanes, Fr. 2 (from Athenaeus 10.413); Euripides, Autolycus Fr. 282, 16-28; Isocrates, Panegyricus 1-2; Origin, Contra Celsum 5.42. 
He had the good fortune to be from an illustrious family and to have beauty, and moreover courage, strength and self-control, things that are truly the greatest of blessings. Indeed the most admirable thing in a man is not only to be unconquered by one's opponents, but also by toil, heat, hunger and libido. ${ }^{17}$

These ideas were widespread; also Pseudo-Dionysius, the author of a rhetorical handbook from the third or fourth century, observes that athletes became famous champions through self-control, self-discipline and training ( $\dot{\alpha} \pi \dot{o}$

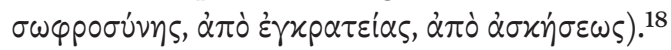

In his home town, a victor of a sacred contest was awarded with exemptions from several types of taxes, in particular liturgies, and was offered honorary seats in public events and a place on the city council. Victors of sacred and eiselastic contests (the most prestigious category of agones) even received considerable monthly pensions from their home cities. Other cities might offer them honorary citizenship or even an honorary seat in the city council. ${ }^{19}$ The athletes' personal networks increased their pull in society even more: they were active members of the local elite and, through the international athletic synod, ${ }^{20}$ even came into contact with the highest authorities.

Apollonios' western counterpart would have had a completely different experience when looking at an agon. His personal network would probably not have included any of the competitors, nor would he have wanted to include them. A western member of the elite may have had some personal experience with training in the gymnasium - as this became fashionable in the Roman baths in the second century - but he did not practice this in front of a public and certainly he did not think of this as a career. As Cornelius Nepos observed, whereas it was a great honor in Greece to be proclaimed Olympic victor, in

17 Dio Chrysostom, Or. 28.12.

18 Pseudo-Dionysius, Ars rhetorica 7.292 (in volume 6 of the Teubner edition of Dionysius of Halicarnassus, Stuttgart 1965).

19 The main sources on these privileges have been collected in Peter Frisch, Zehn agonistische Papyri, Papyrologica Coloniensia 13 (Opladen, 1986). This collection does not include the papyri applying for the monthly pensions, however. For these see esp. SPP V 54-56, 69-70 and 74 (spP Studien zur Palaeographie und Papyruskunde, ed. C. Wessely. Leipzig 1901-1924).

For this association see Henri W. Pleket, "Some aspects of the history of the athletic guilds," Zeitschrift für Papyrologie und Epigraphik 10 (1973), 197-227 and Sofie Remijsen, The End of Greek Athletics, pp. 230-249. 
Rome such an achievement would be deemed unrespectable. ${ }^{21}$ Even when agones spread to the West, the participants continued to originate from the eastern half of the Empire.22

The reason why well-off-citizens socialized in the West did not want to make a career as an athlete is that in the western mindset people continued to think about athletic contests in the terms of a public performance. ${ }^{23}$ The act of performing was surrounded by suspicion: people who made a living out of creating a false or staged reality could not be trusted. ${ }^{24}$ Performing was hence seen as an immoral act, as problematic as other types of immoral acts and crimes. The law thus put the performers on one line with prostitutes, criminals, and other kinds of offenders. These were all disadvantaged by the legal state of infamia. This limitation of citizen rights implied that they were not protected from corporal punishment, could not lay an accusation in a public court, could not become members of city councils, and could not contract legal marriages. ${ }^{25}$ The participants of the agones were legally exempted from the burden of infamia, ${ }^{26}$ but since the agones represented only a small number of all the games on offer in the western half of the Empire, this did not change widespread ideas. A good indication that the western perception of agones did not put the contest central, but the public nature of the activity, is the Latin umbrella term for what we call 'games': spectacula or 'shows'. This is, for example, the word Suetonius uses in the Lives of the Caesars to cover all the games listed

21 Cornelius Nepos, Praefatio 5: Magnis in laudibus tota fere fuit Graecia victorem Olympiae citari, in scaenam vero prodire ac populo esse spectaculo nemini in eisdem gentibus fuit turpitudini. Quae omnia apud nos partim infamia, partim humilia atque ab honestate remota ponuntur.

22 See, for example, Maria Letizia Caldelli, L'Agon Capitolinus, pp. 90-92, on the participants of the Kapitolia in Rome.

23 See also Plutarch, Roman Questions 273 on the Roman suspicion of athletics, in which he explains that the Romans did take over the habit of oiling the body and exercising naked, but especially in the private sphere of the home because this did not represent an error.

Cf. Jack Goody's anthropological model of the ambivalence of performance: Representations and Contradictions: Ambivalence towards Images, Theatre, Fiction, Relics and Sexuality (Oxford and Malden, Mass., 1997), especially pp. 103-104, where he applies his theory to Roman actors.

25 Catharine Edwards, The Politics of Immorality (Cambridge, Eng., 1993), pp. 123-26; Hartmut Leppin, "Between marginality and celebrity: Entertainers and entertainments in Roman society," in The Oxford Handbook of Social Relations in the Roman World, ed. Michael Peachin (Oxford, 2011), pp. 671-672.

$26 \quad$ Dig. 3.2.4.pr. 
by an emperor. ${ }^{27}$ This category of 'show' was later taken over by western Christians, as is illustrated by the title and structure of the first Christian polemic against games: Tertullian's De spectaculis discusses circus games, theater plays, amphitheater events, and agones.

The Greek equivalent of the Latin word spectaculum is $\theta \dot{\varepsilon} \alpha$. This term was not, however, used for agones, which were therefore not considered 'shows'. ${ }^{28}$ Within Greek culture, the defining feature of the agon was its competitive character, not the fact that is was also eagerly viewed by a crowd. The spread of gladiator shows did not change this. Since for every amphitheater event, the public could watch dozens of agones, the foreign newcomer did not challenge the existing model of what 'games' were. People in the Greek-speaking East did not create an umbrella term such as 'games'. All mental categories are based on distinctions that are meaningful only within a certain cultural framework. The sociologist Eviatar Zerubavel expressed this as follows in his standard work on categorization processes: "Discernible only through society's mental glasses, islands of meaning are invisible to anyone not wearing them."29 In the East, one was used to think in terms of contests, not in terms of public-oriented shows.

Several non-agonistic performers benefited from the positive perception of competition in the eastern Mediterranean. Here, gladiators were not burdened by associations with infamy. Often, they were compared to athletes: some of the best gladiators received multiple citizenships after they were freed, just like athletes did after victories, and the formulas on the funerary epitaphs of gladiators were inspired by the agonistic ideology. Gladiators never rose as high as athletes - the organizational procedure was taken over from the West, including the recruitment from slaves and men in financial need - but they were more respected than their colleagues in the West. ${ }^{30}$ Mimes and pantomimes, which in the West enjoyed an extremely ambivalent status, were in the third century allowed to compete in several agones. For them, victories and the

27 See, for example, Suetonius, Augustus 43-44, on the spectacula organized by Augustus. He mentions actors, gladiators, venationes, athletic contests, a staged naval battle, and circus games.

28 Jean-Yves Strasser, "Études sur les concours d'Occident," Nikephoros 14 (2001), 112-13.

29 Eviatar Zerubavel, The Fine Line. Making Distinctions in Everyday Life (Chicago and London, 1991), p. 81.

30 Louis Robert, Les gladiateurs dans l'orient grec (Amsterdam, 1971), p. 263; Christian Mann, Gladiatoren im Osten, pp. 109; $156-74$. 
concomitant privileges, such as honorary citizenship, tax exemptions, etc., opened the way to upward social mobility. ${ }^{31}$

\section{Watching Athletic Contests in the Fourth Century}

In $\mathrm{AD}_{38}$ or 384 Libanius, then about seventy years old, devoted a speech (Oratio 10) to the Plethron, a large palaistra-like structure (a plethron is 3om.) built by Didius Julianus in the center of Antioch to accommodate the preliminary combat matches of the local Olympic games. In the month preceding the games, the athletes who wanted to participate trained and competed here together under the eye of the Olympic umpires so that the best could be selected to compete in the actual contest in the stadium of suburban Daphne. The nearby xystos (a covered running track) probably housed the running events. ${ }^{32}$ Originally, the candidate-competitors had fought on the wrestling ground of the Plethron under the eyes of only a few spectators, as at first the Plethron had only two rows of seats. In the mid-fourth century, however, the president of the Olympics, a notable called Argyrios, wanted to make his presidency more memorable with a benefaction and doubled the number of seats. In the sphere of competitive display, Libanius' uncle Phasganios wished to outdo his predecessor and added four more rows to the four then in existence. In the $380 \mathrm{~s}$ Proklos too, who was comes Orientis when Libanius wrote this speech, wanted to bring luster to his office with a benefaction that would please the crowd, and decided to donate even more seats.

Libanius used his rhetorical skills to protest against this plan. The extra seats could only have negative effects. They would be taken up by schoolboys, workmen, and idlers, who shouted loudly with every move of the athletes. Their disorderly and licentious behavior would disturb the solemn atmosphere of the Olympics and could perhaps even lead to riots in the city.

It is not clear to what extent the atmosphere during these matches actually changed in the course of the fourth century. The idealized past with just two rows of seats was only experienced by Libanius as a child, when - according to

$31 \quad$ Ruth Webb, Demons and Dancers. Performance in Late Antiquity (Cambridge, Mass. and London, 2008), pp. 25-35. For the ambivalent position of pantomimes see also Ismene Lada-Richards, Silent Eloquence. Lucian and Pantomime Dancing (London, 2007). Chronographia. Corpus Fontium Historiae Byzantinae 31 (Berlin, 2000). For the prelimi-

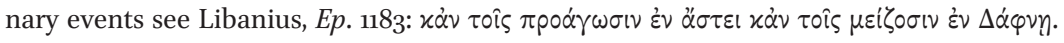

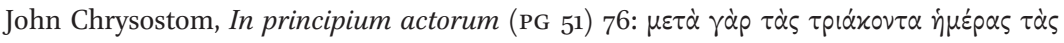

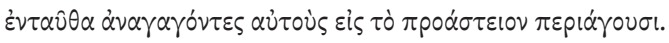


this speech - only the trainers and patrons of the athletes were there to watch, not schoolboys such as himself. Though obviously a smaller crowd made less noise, it is unlikely that the matches in the combat sports - indisputably the most popular athletic events throughout the imperial period - were ever watched in a solemn manner. It was always normal for spectators to support one athlete more than the other and to react emotionally to the moves they made in the course of the match. ${ }^{33}$ What was new, however, was the lack of technical knowledge among even the upper-class part of the public.

In the first half of the fourth century, the ephebate disappeared. Dating this evolution more precisely is difficult: because of changes in the epigraphic habit, the inscribed lists of ephebes, which form the best evidence for the ephebate in the Roman Empire, already disappear in the later third century. Some disparate pieces of evidence suggest that several cities still had an ephebate in the early fourth century, but by the middle of the century the sources are completely silent. ${ }^{34}$ The abandonment of this educational institution did probably not result from a formal decision of various city councils, as the city did not have a major role in the organization of the ephebate in the imperial period. Most offices were either filled by ephebes themselves or by older family members. Therefore, the disappearance of the ephebate implies a loss of public support for the institution that aimed to educate local citizens through a program focused on athletic training and participation in local feasts. ${ }^{35} \mathrm{~A}$ diminishing public support for training in the gymnasium is also reflected by the renovations of palaistras, which became less suitable for intensive sports with the re-

Polybius 27.9 offers a nice example of the public siding with the underdog in the third century вс. Cf. Garrett G. Fagan, The Lure of the Arena. Social Psychology and the Crowd at the Roman Games (Cambridge, 2011), pp. 189-229 on the psychological reaction of people watching sport and its applicability on Antiquity.

Menander Rhetor 396, ed. D.A. Russell and N.G. Wilson, Menander Rhetor (Oxford, 1981). He writes in the late 3 rd or early 4 th $c$. that a young man should recall the shared exercises in the palaistra when making a speech seeing off a friend. According to Libanius, Or. 1.23 the whipping contest in Sparta, which was connected to the local ephebate, still existed circa 330. P.Oxy. I 42 attests a local ephebic competition in Oxyrhynchus in 323 . The last evidence for the ephebate is a kosmetes (the official responsible for the ephebate in Egypt) in P.Ant. I 31, a document of 347 from Antinoopolis.

Hans-Ulrich Wiemer, "Von der Bürgerschule zum aristokratischen Klub? Die athenische Ephebie in der römischen Kaiserzeit," Chiron 41 (2011), 487-537, esp. pp. 510-15 and 51828. His argumentation sometimes confounds the disappearance of evidence with a disappearance of practices. His view that an education that socialized the youth as local citizens was no longer in demand is convincing, however. 
moval of water basins and the addition of pavements. ${ }^{36}$ Athletics did not disappear completely as an elite activity - the idea that this was indecent only became dominant in the later fifth or even sixth century ${ }^{37}$ - but it did become less common.

The second, and more striking change, is the shift in moral discourse. The idea that the reaction of the crowd was a bad thing was not a topos in earlier moralist literature, at least not in the East. The traditional moral criticism on professional athletics focused on the lifestyle of the competitors: they were considered gluttons who did not contribute to society in any meaningful way. ${ }^{38}$ The presence of the crowd and its behavior was never questioned. That Libanius argues against the treatment of the Antiochene Olympics as a spectacle shows that he, like his contemporaries, had internalized the category of 'shows'. Whereas the conservative Libanius did not agree with this categorization, many of his contemporaries do seem to have used this category in an inclusive way. Basil puts pankratiasts on one line with mimes and venatores. ${ }^{39}$ John Chrysostom uses the term $\theta$ ćatpov for the entire range of shows: acting, horse racing, athletics, acrobats, etc. ${ }^{40}$ In many examples such as these, it is unclear whether the athletes meant are circus performers or competitors of agones, but Palladius unambiguously describes the Antiochene Olympics as $\theta \varepsilon \dot{\varepsilon} \alpha \hat{\omega} \nu$

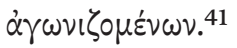

With the new category of 'show' came a strong focus on the spectators. Not unlike Libanius, Basil explained that the disgusting noise and shouting of the crowd were a reason why potential sponsors should not pay for the shows of pankratiasts, mimes, or venatores. John Chrysostom repeatedly warns for the immorality of performers, not for their personal lifestyle, but for the impact on

36 Fikret Yegül, Baths and Bathing in Classical Antiquity (Cambridge, Mass. and London, 1992), pp. 307-313; Martin Steskal, "Bemerkungen zur Funktion der Palästren in den Ephesischen Bad-Gymnasium-Komplexen," Jahreshefte des Österreichischen Archäologischen Institutes in Wien 72 (2003), 227-39, esp. pp. 234-37.

37 The participants of the Antiochene Olympics were well-to-do individuals until the end of these games in 520. See Malalas 12.10. Procopius, De Bellis 1.13.29-38 identifies a bath attendant of the general as an athletics trainer from Constantinople. According to Suidas, s.v. Mévavopos this Menander undressed to exercise in the palaistra in the 570s, but later repented this indecency.

38 Cf. n. 16.

39 Basil of Caesarea, Homilia in illud: Destruam horrea mea 3. Ed. Yves Courtonne, Saint Basile: Homélies sur la richesse (Paris, 1935).

40 Christoph Jacob, Das geistige Theater: Ästhetik und Moral bei Johannes Chrysostomus (Münster, 2010), p. 27.

$41 \quad$ Dialogus de vita Joannis Chrysostomi (sc 341) 16.104. 
the public of the stories they staged. ${ }^{42}$ Many more moralizing authors argued that shows caused all kinds of illicit behavior (brawls, licentious sexual behavior, gambling, etc.), especially in Christian works. ${ }^{43}$ The difference between Christian and pagan moral criticisms should not be overstated, however; the major difference is in tone, not in argumentation. Obviously, Christian authors were stricter; they generally pleaded for complete abstinence from games. The tone of the extremely topical discourse was set by Tertullian at a time when the animal sacrifices at the games left no room for a milder view, and in the heresyobsessed world of the fourth century it was hardly safe to publish a far milder view than the traditional one.

The reason why many people in the later fourth century saw athletic competitions as a kind of 'show' has little to do with Christianization and cannot be entirely explained by the lack of personal experience with athletics among large parts of the spectators either. Foremost, it indicates that the agon was no longer the model for understanding games. Around the second quarter of the century, the agones lost their dominant position among games in the East. Christianization is not a major factor in this process, as animal sacrifices were no longer executed at the agones at this point and there is enough evidence for Christian involvement in games in the later fourth century. The difficulties on the agonistic circuit were a side effect of the centralization of power in the East. The decrease in political initiative on the city level and the partial confiscations of city possessions created obstacles for the strongly city-driven organizational procedures of the games. ${ }^{44}$ While agones in provincial capitals were saved by the active engagement of high officials - such as the aforementioned comes Orientis - in smaller cities athletic contests disappeared. In the later fourth century, the circuit of agones on which professional competitors traveled still existed, ${ }^{45}$ but it was far smaller than it had been a century before. The development of government structures in the East also led to the construction of circuses adjacent to tetrarchical palaces (e.g. at Nikomedia, Thessaloniki, or

42 Christop Jacob, Das geistige Theater, pp. 90-91. Cf. Blake Leyerle, Theatrical Shows and Ascetic Lives: John Chrysostom's Attack on Spiritual Marriage (Berkeley, Cal. and Los Angeles, 2001), p. 43: "On the most basic level, John indicts the theater for its falsity, for pretending to be what is not."

43 See e.g. Werner Weismann, Kirche und Schauspiele: Die Schauspiele im Urteil der lateinischen Kirchenväter unter besonderer Berücksichtigung von Augustin (Würzburg, 1972), pp. 69-122.

44 This process as explained in detail in Sofie Remijsen, The End of Greek Athletics, pp. 289320. For the removal of the sacrifices see pp. 184-187.

45 CIL VI $10154(367-375)$, l. 3-5: Filumenum in omni aclhetico certamine ab Oriente ad Occidente(m) usq(ue) victorem. 
eventually at Constantinople), which in turn stimulated a fashion for circus games, first in the imperial residences and soon after in the surrounding cities. $^{46}$

Circus games were not just chariot races. In fact, they offered various types of entertainers the opportunity to perform. Fifth and sixth-century circus programs from Egypt ${ }^{47}$ show that in between the chariot races all kinds of shows were put on: mimes, small venationes, acrobats, and even athletic contests - no gladiators, however, these lost popularity in the fourth century and disappeared completely in the early fifth. Extra entertainments in the circus are likewise attested in earlier sources. Ammianus Marcellinus for example describes how in the early 350 s Gallus was absorbed in seven simultaneous boxing matches in the circus. ${ }^{48}$ With the circus games came thus a mix-and-match format for games. Half of the so-called 'circus programs' on papyrus do not even mention horse races, ${ }^{49}$ but give a selection of various other entertainments - like the modern circus. Unlike the agones, to which free men with higher than average means traveled large distances in order to compete voluntarily, with no guaranteed winnings, these shows worked with hired performers.

In the later fourth century, athletes therefore competed on one of two circuits. ${ }^{50}$ Those who had the means to hire private trainers, to travel independently over large distances, and to become members of the influential but exclusive international athletic association, continued to compete in the agones. People with the physical build for athletics, but not the financial means, could make a living - or often just a little on the side - by performing in shows of the kind sketched above. Though these athletes are underrepresented in the sources - as all members of the lower classes - they would, by the end of the fourth century, have been the most common type. From a story of the Apophthegma Patrum it can be deduced that these circus athletes cooperated in troops. ${ }^{51}$ In this short story, a magistrate is saved by God from dying in a shipwreck; he shares this ship with a group of pammacharii who were, like him, traveling from Tyre to Constantinople - two major cities with a circus and

46 Discussion of the tetrarchical circuses in John H. Humphrey, Roman Circuses: Arenas for Chariot Racing (Los Angeles 1986), pp. 633-638.

47 P.Oxy. XXXIV 2707, P. Bingen 128, P.Oxy. LXXIX 5216.

48 Ammianus Marcellinus 14.7.3.

49 P.Harrauer 56, P.Oxy. LXXIX 5215, 5217.

5o For a more extensive discussion of these two circuits see Sofie Remijsen, The End of Greek Athletics, pp. 220-230.

$5^{1} \quad$ Apophthegmata 39, ed. François Nau, "Histoire des solitaires égyptiens," Revue de l'Orient Chrétien 12 (1907), 171-181. 
hence ample opportunities to get hired. Pammacharii were athletes specialized in pammachon, a more free-style combat sport that got included at certain agones from about AD 300 onward.$^{52}$ It is remarkable that a whole group of athletes travelling together had the same specialty. For athletes on the agonistic circuit, it would have been a disadvantage to consistently attend the same competitions as one's direct competitors, for the same one or two would always win. On the circus circuit, however, this was an advantage, as circus directors would be more likely to hire an established troop. In the huge infrastructure directors liked to set up several matches simultaneously, as in Ammianus Marcellinus' passage with seven boxing matches. In this way one insured visibility at the various ends of the circus. In closely cooperating groups, the athletes had, moreover, in-depth knowledge of all their colleagues' tricks and weaknesses and could use this knowledge to present a more appealing show. Not all matches between two contestants, both fighting for the victory crown, were equally interesting for the public. Though a close-fought match with unexpected turns in fate could be very exciting, a match in which little happened, an unequal match in which the better athlete beat the beginner knock-out within a minute or two, or a match relying mainly on intricate defensive skills could not enthuse the spectators to the same extent. Contestants who knew each other and did not need to win in order to get their wages could avoid such situations.

The only certain depictions of circus athletes, relief scenes on a bronze vase connected by an inscription along the neck to the Green circus faction, ${ }^{53}$ confirm that the style of fighting of circus athletes included various theatrical gestures. The vase shows several matches, mostly figuring the successful pankratiast Privatulus. More interesting is the behavior of the losers: they allowed Privatulus to make a big show of his victory - and of their defeat. In one scene, the triumphant victor put his foot on the stretched-out body of the loser, who was kind enough to remain flat on the ground. In the next, Privatulus held the loser by his neck and his behind, and threw him like a sack of flour - which would be practically impossible without cooperation of the victim. It is impossible to say whether these matches were manipulated to the same extent as for

$5^{2} \quad$ For this sport see Sofie Remijsen, "Pammachon: A new sport," Bulletin of the American Society of Papyrologists 47 (2010), 185-204.

53 Published in Dietrich O.A. Klose and Thomas Klein, "Werbung für den Wettkampf in spätantiker Zeit: Die Bronzevase des Privatulus aus archäologischer und philologischer Sicht," in Der gymnische Agon in der Spätantike, eds. Andreas Gutsfeld and Stephan Lehmann (Gutenberg, 2013), pp. 143-50. 
example American pro wrestling ${ }^{54}$, but this certainly seems a better analogy than modern Olympic wrestling. The performance of these athletes was hence more adopted to the new spectacle culture than the traditional agones, where even the since long unpopular pentathlon remained on the program. ${ }^{55}$

\section{Looking at Athletes in the Fourth Century}

When in the later fourth century another fictional Apollonios, a descendant of our earlier protagonist, saw a man engaged in a wrestling match, he had a different experience from his ancestor. He may have had some difficulty becoming absorbed by the match: he did not know the rules and techniques of the sport from personal experience, so it was hard to make out who was winning, if the athletes did not slightly overact the situation. It also made it difficult for Apollonios to identify with the men. Nor was it immediately clear what he had to make of them: were they two of these infamous performers from insignificant families who wrestled to make a living or were they instead conservative aristocrats who had followed intensive private training? Without cloths such things were hard to see. Only the context of the match could enlighten him. If after the match, one of the athletes turned out to be interested in marrying Apollonios' daughter, the circus athlete would be mocked for such a pretentious thought. He could not even legally marry, for he fell under the restrictions of infamia. When the competitor of an agon asked him the same question, Apollonios was flattered, however. That young man talked as if he had received an outstanding literary education - perhaps at the school of Libanius ${ }^{56}$ - and several members of his family had held high offices in the imperial administration. Perhaps Apollonios' brother, an abbot in a nearby monastery, would advise against the match, however. With a career devoted to an artificially muscular body and to constantly outdoing others, the young man surely was terribly vain.

54 Very interesting in this respect is Barthes' essay on 'catch', the French variation on pro wrestling, and in particular when he discusses the role-playing of the contestants and over-acting of defeat: Roland Barthes, Mythologies (Paris, 1957), pp. 11-28.

A victory list on bronze plate from Olympia attests fourth-century sprinting specialists and a pentathlon victor of 381 . Cf. Joachim Ebert, "Zur neuen Bronzeplatte mit Siegerinschriften aus Olympia (Inv. 1148)," Nikephoros 10 (1997), 217-33.

$5^{6}$ In Epistulae 1278 and 1279, Libanius discusses two brothers who took part in the Antiochene Olympics. He praises them as well for their enthusiasm for rhetoric, which must be the context in which Libanius encountered them. 
From the later fourth century on, the textual and even visual sources on competitors in the agones are characterized by a struggle to distinguish them from lower-class performers. In the field of self-representation, the competitors had lost several important tools in comparison with their predecessors. Victors still enjoyed prestigious privileges, but Diocletian had limited some of these to athletes who had won at least three sacred contests, one of which had to be in Greece or Rome. ${ }^{57}$ This limited the value of a single 'sacred victory'. In the late third century, honorary monuments for members of the local elite moreover disappeared, as a result of changes in the political culture. Athletic victors were among the victims: they were no longer awarded statues in the city center. Changes in the value-set were not to their advantage either: the choice for an ascetic lifestyle - which denied the body rather than developing it - found wide public support from the third century on. ${ }^{58}$ Also the Christian value of humility was in obvious contradiction with the passion for winning contests. ${ }^{59}$ Passages such as Malalas 12.10, in which he describes the competitors of the Antiochene Olympics explicitly as very wealthy - they brought gold and slaves - and moreover as chaste, suggests that the late-antique author could not expect his readers to find this self-evident. Fourth-century anecdotes show that athletes were often suspected of negative actions, such as black magic. Libanius describes for example in his autobiography how his enemy Festus tried to harm him about 365 with the help of a certain Martyrius, whom Festus thought to be a sorcerer because of his attachment to wrestlers. According to Ammianus Marcellinus, in Rome the wrestler Asbolius was similarly accused of poisoning in $369-370.60$

A good illustration of the attempts of the competitors to keep their group 'clean' is a long and detailed agonistic metaphor in John Cassian's Institutions (SC 109) 5.12. ${ }^{61}$ After having spent the larger part of his life in the eastern Mediterranean, John Cassian founded a monastery in Marseille circa 415. The Institutions (written circa 420) discuss the ideal organization of a monastery. The passage of interest to us is a long commentary on a famous agonistic metaphor by Paul: "An athlete is not crowned unless he competes according to the rules"

57 Cod. Iust. 10.54.1; P. Lips. I 44.

$5^{8}$ Peter Brown, The Body and Society: Men, Women, and Sexual Renunciation in Early Christianity (New York, 1988), e.g. pp. 191-192, 202. See also James A. Francis, Subversive Virtue. Asceticism and Authority in the Second-Century Pagan World (University Park, Pa., 1995), who focuses on pagan asceticism and on social acceptability.

59 Cf. Augustine, Confessiones 1.10, which describes the ambition to win contests as a sin.

6o Libanius, Or. 1.156-159; Ammianus Marcellinus 28.1.8.

61 Discussion and commentary of some agonistic details in Alois Koch, "Unbekannte Details der antiken Agonistik?," Nikephoros 20 (2007), 209-211. 
(2 Tim 2:5). In order to explain the validity of Paul's saying, John Cassian elaborated the image further, adding many details on the selection of athletes, which he must have known from his youth and longer residencies in cities in the eastern Mediterranean. He wrote that, before being allowed to compete, three aspects of a candidate's life were carefully examined: it had to be established that no aspect of his life was defiled by infamia and that he was not a slave and he had to prove his technique and strength. Athletes had to start competing as boys and, before competing as an adult in the top games, should have proven to be at least equal to other athletes, preferably by having beaten them at other games. The exclusion of slaves had always been a rule at the agones and was hence not specifically directed against circus athletes. ${ }^{62}$ The track record the candidates needed to present did enforce an extra barrier. Most obviously directed against circus athletes was the exclusion of persons marked by the legal status of infamia. This affected everyone who made an exhibition of himself in front of a public and who contended or acted for gain. ${ }^{63}$ This definition included circus athletes (who contended for gain in front of a public), but not the competitors of the sacred contests, who had long been exempted. ${ }^{64}$ For the exclusion of circus athletes from agones, the juristic reasoning was reversed: infamia was no longer only a consequence of performing, it was also a ground for exclusion. ${ }^{65}$ In order to avoid association with performers, the well-to-do athletes made sure they would never compete against them. No dignity could be gained from defeating them, but being defeated by them would be twice as shameful. Like Libanius, the competitors of the agonistic circuit fought against the tendency to categorize agones as spectacles.

62 See e.g. Artemidorus, Onirocriticon 1.62.

63 Dig. 3.2.2.5: Ait praetor: "Qui in scaenam prodierit, infamis est". Scaena est, ut Labeo definit, quae ludorum faciendorum causa quolibet loco, ubi quis consistat moveaturque spectaculum sui praebiturus, posita sit in publico privatove vel in vico, quo tamen loco passim homines spectaculi causa admittantur. Eos enim, qui quaestus causa in certamina descendunt et omnes propter praemium in scaenam prodeuntes famosos esse pegasus et nerva filius responderunt.

64 Dig. 3.2.4.pr: Athletas autem Sabinus et Cassius responderunt omnino artem ludicram non facere: virtutis enim gratia hoc facere. Et generaliter ita omnes opinantur et utile videtur, ut neque thymelici neque xystici neque agitatores nec qui aquam equis spargunt ceteraque eorum ministeria, qui certaminibus sacris deserviunt, ignominiosi habeantur.

65 Whereas scholarship on Greek athletics in the 1980 strongly focused on disconnecting it from the notion of amateurism from the later 19th and early zoth century - esp. David C. Young, The Olympic Myth of Greek Amateur Athletics (Chicago, 1984) - for late antiquity the analogy actually works. 
On mosaics, the tendency to actively dissociate the participants of the $a g$ ones from athletic performances may be reflected in the fashion for depicting these athletes by themselves - either full-figure or (usually) only the busts within a decorative frame that separated them from others. ${ }^{66}$ The date of most mosaics is disputed, but one of the most representative examples of this genre - a mosaic with athletic busts from Aquileia - can certainly dated after AD 348 on the basis of numismatic evidence embedded in the mortar. When individual athletes are depicted within frames, the emphasis lies on the fame and victor status of the athlete. This is the exact opposite of the theatrical staging of defeat on the bronze vase discussed before.

\section{A Romanization of Games?}

This study described how, by the later fourth century, games in both the western and eastern half of the Empire were organized according to the Roman model, which allowed the organizer to flexibly mix and match shows according to taste, opportunity, and occasion. The incorporation of athletics in the Roman-style games even led to the Latinization of athletic terms in Greek. The specialists of the late-antique Greek sport pammachon were called pammacharii, with a Latin suffix. The life of Saint Theodore of Sykeon records an anecdote in which the saint, visiting Constantinople in the reign of Mauricius (582-6o2), healed a wrestler who was possessed by an evil spirit. This athlete with a traditional Greek specialty is described, in a Greek text, with the Latin term $\lambda$ oux $\alpha \dot{\tau} \tau \omega \rho$ (luctator). ${ }^{67}$ From the later fourth century on, games were widely perceived through the Roman cognitive category of 'show' or spectaculum. The unified spectacle landscape of the fourth century was therefore essentially a Roman one. This leads to the question of how this process of cultural unification fits into the Romanization debate.

As has been aptly explained by Kaldellis ${ }^{68}$, the identity of many people in the late-antique eastern Roman Empire was composed of three main constitu-

66 Anke Bohne, Bilder vom Sport: Untersuchungen zur Ikonographie römischer AthletenDarstellungen, Nikephoros Beihefte 19 (Hildesheim, 2011), K1 (Aquileia), K23, K51, K55, $\mathrm{K}_{56}$, K61, K85b, and K10o.

67 Vita Theodori Syceotae 88, ed. André-Jean Festugière, Vie de Théodore de Sykeôn (Brussels, 1970).

68 Anthony Kaldellis, Hellenism in Byzantium: The Transformations of Greek Identity and the Reception of the Classical Tradition (Cambridge, Eng., 2007), pp. 1-187, esp. pp. 1-6 and 42-119 (a detailed discussion of how people in the late-antique East presented themselves as Romans). 
tive elements. They could at the same time have a sense of being Greek, of being Roman, and of being Christian. As noted in the introduction, feeling Greek was not really in contrast with an adherence to the Roman Empire, rather on the contrary, the former could enforce the latter. In the intellectual discourse of the imperial period, however, Greek identity was more prominent. In the course of the fourth century, this emphasis shifted. Until then, people in the Greek East never actually called themselves Romans, but in the fourth century they started to identify themselves as Romans, and by the early Byzantine period, they generally did so. This change is linked to administrative changes, as well as to new and more negative meanings of the word 'Greek' ("E $\mathrm{\lambda} \lambda \eta \nu$ ).

From the Severan period onwards, people in the East became more actively engaged in the government and administration of the Empire, and more and more eastern notables were elevated to high ranks. With the Constitutio Antoniniana, every free man had moreover officially become a Roman citizen, carrying a Roman nomen. All fell under Roman law, which was, with some delay, increasingly applied. The emperors moreover started to spend more time in the East. In the late third century, the influence of eastern provincials in the Empire increased even more because of the growing state apparatus with the reorganization by Diocletian. At the same time, Christianity was spreading rapidly. In this context $\varepsilon \lambda \lambda \eta \nu$ became a synonym for 'pagan' and, consequently, being 'Greek' became a charged notion. From the fourth century on, it was gradually relegated to the domain of elite culture, where traditional paideia was still appreciated and Greekness could thus still play a positive role.

We should ask, therefore, in how far the adaptation of Roman practices and views with respect to athletics and games in general is related to this growing readiness to define oneself as a Roman rather than a Greek. Social customs such as going to the public baths or to the games could function as identity markers. One could also wash or exercise at home or - if one had the money - even look at performers in a private context. Visiting public gymnasia and games, however, were regular public activities that integrated a person in the community. ${ }^{69}$ Being seen doing these activities was as essential as doing them. This made them potential identity markers, but what identity did they mark? When a 'Greek' stopped with his intensive training in the palaistra in favor of more leisurely activities in the baths and started enjoying athletic competitions as shows rather than as contests, did this make him feel more 'Roman'? This would not only require that he realized that these practices were

69 Cf. Yegül, Baths and Bathing in Classical Antiquity, p. 4 on the importance of bathing practices for the integration in Roman culture. 
typical of Greek and Roman culture - whereas it is easy to argue that practicing athletes was a recognizably 'Greek' activity, leisurely enjoyment of the bath or watching 'spectacles' were too similar to common practices in the East, and spread too gradually, to be recognized as distinctly 'Roman'70 - it also presumes that these cultural origins directed people's behavior. 'Romanization' is a concept with a complex history and shifting meaning, but it generally implies a conscious process of cultural change, directed by an awareness of differences between the Roman and the preexisting culture ${ }^{71}$.

Interesting theoretical research on ethnicity and identity has in the last decade been done by Rogers Brubaker. One of his major points is that 'groups' are never stable; the sense of belonging to a certain group is activated only by circumstances. He therefore prefers the variable 'groupness' over the constant 'groups' as an analytical category. People have a plurality of identities that can be activated in a given situation, but not all are activated in everyday life. ${ }^{72}$ People in the ancient world may, in specific situations, have ascribed to the groups of the Romans or the Greeks or to both, but in everyday life this identity did not necessarily matter. Social affiliations are often given preference to memberships of ethnic, political or religious groups. ${ }^{73}$ The groupness that is activated by many social practices, which we can study through ancient sources, is membership of the elite. As has been pointed out by scholars focusing on the 'self-romanization' of local elites, the reason why some people in the provinces copy certain Roman objects, buildings, or practices is often their elite

70 The most telling source for this is Lucian's Anacharsis, in which the Skythian sage discusses as an outsider the respect for athletics in Athens with Solon. Jason König, Athletics and Literature in the Roman Empire (Cambridge, Eng., 2005), pp. 46-47, 80-96 discusses this dialogue in detail. Bardesanes Edessenus, The Book of the Laws of Countries 599 even takes athletics as the most characteristic feature of the Greeks. For this Syriac text, see the edition by H.J.Willem Drijvers, The Book of the Laws of Countries: Dialogue on Fate of Bardaisan of Edessa (Assen, 1964). For the gradual change in bathing practices, see Fikret Yegül, Baths and Bathing in Classical Antiquity, pp. 250-256 (on the large complexes combining Roman baths with Greek gymnasia, developed in the first century AD) and pp. 307-313 (on the gradual disappearance of the palaistra).

71 A clear and brief summary of the debate in Christian Mann, Gladiatoren im Osten, pp. 16-23.

72 Rogers Brubaker, Ethnicity without Groups. (Cambridge, Mass. and London, 2004), esp. pp. $1-65$.

73 Éric Rebillard, Christians and their Many Identities in Late Antiquity, North Africa, 200-450 CE (Ithaca, N.Y. and London, 2012), p. 74. Cf. Rogers Brubaker, Ethnicity without Groups, pp. $44-45$ on the importance of self-understanding and social location for individual and collective action. 
character. ${ }^{74}$ Acculturation processes in the East are far more complicated than those in the West, because Greek culture had in the many areas where it was not indigenous the same elite connotation. Because athletics was a typical elite practice, it could in the East be instrumentalized for constructing a Greek as well as a Roman identity, but people engaged in it (as participant or organizer) foremost because it ingrained them in the elite. ${ }^{75}$

The unification of the Roman spectacle landscape in the fourth century was not caused by a preference of the 'Roman' over the 'Greek' tradition. As Greg Woolf already pointed out, people in the East did not frequently construct their 'Greek' identity on the basis of customs such as bathing or watching games, but instead focused on language or history. ${ }^{76}$ The tetrarchs built circuses next to palaces, because they knew that these would give them a strong instrument for imperial propaganda. Although the format was different, the sports and arts practiced on stage were not unlike what the people were used to, and for that reason they rapidly spread, not because the new games were more 'Roman'. At a time when the city-driven organization of the agones was curbed by the centralization of power, the new format was above all more flexible. The intrusion of a 'Roman' way of thinking about games was an unintended consequence of the new political structures of the fourth century, which, as Inglebert points out in the opening chapter of this book, were indeed an important factor in the unification of East and West in the fourth century. The 'Roman' origin can be perceived by us, but it is not made explicit in our few sources and was probably not recognized as such by many people in the fourth century. In late antiquity, attitudes to spectacles are in fact only discussed with the aim of identity construction in the context of Christian sermons, where the abstinence from games is promoted as part of a distinctively Christian identity. ${ }^{77}$ The acculturation process in the field of games is therefore neither cause nor consequence of the development of a more prominent Roman identity. If

74 E.g. Ramsay MacMullen, "Notes on Romanization," Bulletin of the American Society of Papyrologists 21 (1984), 175-177.

See, for example, the work of Onno van Nijf: "Athletics and Paideia" (cf. n. 14) and "Athletics, Andreia and the Askêsis-Culture in the Roman East", Andreia. Studies in Manliness and Courage in Classical Antiquity, eds. Ralph M. Rosen and Ineke Sluiter (Leiden, 2003), pp. 263-286.

$7^{6}$ Greg Woolf, "Becoming Roman, Staying Greek: Culture, Identity and the Civilizing Process in the Roman East," Proceedings of the Cambridge Philological Society 40 (1994), 116143, esp. 125-130.

Katryn Mammel, "Ancient Critics of Roman Spectacle and Sport," in A Companion to Sport and Spectacle in Greek and Roman Antiquity, eds. Paul Christesen and Donald G. Kyle (Malden and Oxford), pp. 612-613. 
one would call this unconscious adaptation of Roman practices Romanization, it is Romanization 'by default': the Greek competitions declined by themselves and the Roman games just happened to be an available alternative. With the eventual disappearance of the agones, the eastern 'Romans' did lose, however, one of the last practices on the basis of which they could - if they wanted construct a Greek identity.

\section{Bibliography}

Mary T. Boatwright, Hadrian and the Cities of the Roman Empire (Princeton, 200o). Anke Bohne, Bilder vom Sport: Untersuchungen zur Ikonographie römischer AthletenDarstellungen, Nikephoros Beihefte 19 (Hildesheim, 2011).

Peter Brown, The Body and Society: Men, Women, and Sexual Renunciation in Early Christianity (New York, 1988).

Rogers Brubaker, Ethnicity without Groups. (Cambridge, Mass. and London, 2004).

Maria Letizia Caldelli, L'Agon Capitolinus. Storia e protagonisti dall' istituzione domizianea al IV secolo (Rome, 1993).

Alan Cameron, Circus Factions. Blues and Greens at Rome and Byzantium (Oxford, 1976).

Michael J. Carter, "Romanization through Spectacle in the Greek East," in A Companion to Sport and Spectacle in Greek and Roman Antiquity, eds. Paul Christesen and Donald G. Kyle (Malden and Oxford), pp. 619-621.

Nigel B. Crowther, "Euexia, eutaxia, philoponia: Three contests of the Greek gymnasium," Zeitschrift für Papyrologie und Epigraphik 85 (1991), 301-304.

H.J. Willem Drijvers, The Book of the Laws of Countries: Dialogue on Fate of Bardaisan of Edessa (Assen, 1964).

Joachim Ebert, "Zur neuen Bronzeplatte mit Siegerinschriften aus Olympia (Inv. 1148)," Nikephoros 10 (1997), 217-33.

Catharine Edwards, The Politics of Immorality (Cambridge, Eng., 1993).

Garrett G. Fagan, The Lure of the Arena. Social Psychology and the Crowd at the Roman Games (Cambridge, 2011).

James A. Francis, Subversive Virtue. Asceticism and Authority in the Second-Century Pagan World (University Park, Pa., 1995).

Peter Frisch, Zehn agonistische Papyri, Papyrologica Coloniensia 13 (Opladen, 1986).

Francesca Garello, "Circenses. Sports as a Vehicle of Popular Consesus and Control of the Masses in Imperial Rome," in La comune eredità dello sport in Europa. Atti del $1^{\circ}$ Seminario Europeo di Storia dello Sport, eds. Arnd Krüger and Angela Teja (Rome, 1997), pp. 100-106.

Jack Goody, Representations and Contradictions: Ambivalence towards Images, Theatre, Fiction, Relics and Sexuality (Oxford and Malden, Mass., 1997). 
Peter Herz, "Seltsame Kaisergentilizien. Beobachtungen zur kaiserzeitlichen Nomenklatur," in Fremde Zeiten. Festschrift für Jürgen Borchhardt, eds. Fritz Blakolmer e.a. (Wien, 1996), pp. 253-259.

John H. Humphrey, Roman Circuses: Arenas for Chariot Racing (Los Angeles 1986).

Christoph Jacob, Das geistige Theater: Ästhetik und Moral bei Johannes Chrysostomus (Münster, 2010).

Anthony Kaldellis, Hellenism in Byzantium: The Transformations of Greek Identity and the Reception of the Classical Tradition (Cambridge, Eng., 2007).

Dietrich O.A. Klose and Thomas Klein, "Werbung für den Wettkampf in spätantiker Zeit: Die Bronzevase des Privatulus aus archäologischer und philologischer Sicht," in Der gymnische Agon in der Spätantike, eds. Andreas Gutsfeld and Stephan Lehmann (utenberg, 2013), pp. 143-50.

Alois Koch, “Unbekannte Details der antiken Agonistik?," Nikephoros 20 (2007), 209-211.

Jason König, Athletics and Literature in the Roman Empire (Cambridge, Eng., 2005).

Ismene Lada-Richards, Silent Eloquence. Lucian and Pantomime Dancing (London, 2007).

Hartmut Leppin, "Between marginality and celebrity: Entertainers and entertainments in Roman society," in The Oxford Handbook of Social Relations in the Roman World, ed. Michael Peachin (Oxford, 2011), pp. 671-672.

Blake Leyerle, Theatrical Shows and Ascetic Lives:John Chrysostom's Attack on Spiritual Marriage (Berkeley, Cal. and Los Angeles, 2001).

Ramsay MacMullen, "Notes on Romanization," Bulletin of the American Society of Papyrologists 21 (1984), 175-177.

Katryn Mammel, "Ancient Critics of Roman Spectacle and Sport," in A Companion to Sport and Spectacle in Greek and Roman Antiquity, eds. Paul Christesen and Donald G. Kyle (Malden and Oxford), pp. 612-613.

Christian Mann, “Um keinen Kranz, um das Leben kämpfen wir!" Gladiatoren im Osten des römischen Reiches und die Frage der Romanisierung (Berlin, 2011).

Zahra Newby, Greek Athletics in the Roman World. Victory and Virtue (Oxford, 2005).

Karin van Nieuwkerk, "A Trade like Any Other": Female Singers and Dancers in Egypt (Austin, Tex., 1995), pp. 187-192.

Onno van Nijf, "Local heroes: athletics, festivals and elite self-fashioning in the Roman East," in Being Greek under Rome. Cultural Identity, the Second Sophistic and the Development of Empire, ed. Simon Goldhill (Cambridge, Eng., 2001), pp. 306-334.

"Athletics, Andreia and the Askêsis-Culture in the Roman East", Andreia. Studies in Manliness and Courage in ClassicalAntiquity, eds. Ralph M. Rosen and Ineke Sluiter (Leiden, 2003), pp. 263-286.

—, "Athletics and Paideia: Festivals and Physical Education in the World of the Second Sophistic," in Paideia: The World Of The Second Sophistic, ed. Barbara E. Borg (Berlin - New York 2004), pp. 203-227. 
Henri W. Pleket, "Some aspects of the history of the athletic guilds," Zeitschrift für Papyrologie und Epigraphik 10 (1973), 197-227.

_ , "Zur Soziologie des antiken Sports," Mededelingen van het Nederlands Instituut te Rome 36 (1974), 57-87.

Éric Rebillard, Christians and their Many Identities in Late Antiquity, North Africa, 200-450 CE (Ithaca, N.Y. and London, 2012).

Sofie Remijsen, "Pammachon: A new sport," Bulletin of the American Society of Papyrologists 47 (2010), 185-204.

Sofie Remijsen, The End of Greek Athletics (Cambridge, Eng., 2015).

Louis Robert, "Deux concours grecs à Rome," Comptes Rendus de l'Académie des Inscriptions et Belles-lettres (1970), pp. 6-27.

- Les gladiateurs dans l'orient grec (Amsterdam, 1971).

Tony Spawforth, "Kapetoleia Olympia: Roman Emperors and Greek Agones," in Pindar's Poetry, Patrons, and Festivals from Archaic Greece to the Roman Empire, eds. Simon Hornblower and Catherine Morgan (Oxford, 2007), pp. 377-390.

Martin Steskal, "Bemerkungen zur Funktion der Palästren in den Ephesischen BadGymnasium-Komplexen," Jahreshefte des Österreichischen Archäologischen Institutes in Wien 72 (2003), 227-39.

Jean-Yves Strasser, "Études sur les concours d'Occident," Nikephoros 14 (2001), 112-13.

Christian Wallner, Soldatenkaiser und Sport, Grazer Altertumskundliche Studien 4 (Frankfurt am Main, 1997).

Ruth Webb, Demons and Dancers. Performance in Late Antiquity (Cambridge, Mass. and London, 2008).

Werner Weismann, Kirche und Schauspiele: Die Schauspiele im Urteil der lateinischen Kirchenväter unter besonderer Berücksichtigung von Augustin (Würzburg, 1972).

Hans-Ulrich Wiemer, "Von der Bürgerschule zum aristokratischen Klub? Die athenische Ephebie in der römischen Kaiserzeit," Chiron 41 (2011), 487-537.

Greg Woolf, "Becoming Roman, Staying Greek: Culture, Identity and the Civilizing Process in the Roman East," Proceedings of the Cambridge Philological Society 40 (1994), 116-143.

Fikret Yegül, Baths and Bathing in Classical Antiquity (Cambridge, Mass. and London, 1992).

David C. Young, The Olympic Myth of Greek Amateur Athletics (Chicago, 1984).

Eviatar Zerubavel, The Fine Line. Making Distinctions in Everyday Life (Chicago and London, 1991).

Ruprecht Ziegler, Städtisches Prestige und kaiserliche Politik: Studien zum Festwesen in Ostkilikien im 2. und 3. Jahrhundert n. Chr. (Düsseldorf, 1985).

Arjan Zuiderhoek, The Politics of Munificence in the Roman Empire. Citizens, Elites, and Benefactors in Asia Minor (Cambridge, Eng., 2009). 
Malalas, ed. Iohannis Thurn, Ioannis Malalae Chronographia. Corpus Fontium Historiae Byzantinae 31 (Berlin, 200o).

Menander Rhetor, ed. D.A. Russell and N.G. Wilson, Menander Rhetor (Oxford, 1981).

Basil of Caesarea, Homilia in illud: Destruam horrea mea 3. Ed. Yves Courtonne, Saint Basile: Homélies sur la richesse (Paris, 1935).

Apophthegmata 39, ed. François Nau, "Histoire des solitaires égyptiens," Revue de l'Orient Chrétien 12 (1907), 171-181.

Vita Theodori Syceotae 88, ed. André-Jean Festugière, Vie de Théodore de Sykeôn (Brussels, 1970). 